\begin{tabular}{l}
\hline The Open Dentistry Journal \\
\hline CrossMark \\
Content list available at: www.benthamopen.com/TODENTJ/ \\
DOI: $10.2174 / 1874210601610010460$
\end{tabular}

REVIEW ARTICLE

\title{
Dental Occlusion and Ophthalmology: A Literature Review
}

\author{
Nicola Marchili ${ }^{*}$, Eleonora Ortu, Davide Pietropaoli, Ruggero Cattaneo and Annalisa Monaco \\ University of L'Aquila, Department of Life, Health and Environmental Sciences, Building Delta 6 Dental Unit, St \\ Salvatore Hospital-Via Vetoio 67100 L'Aquila, Italy
}

\begin{abstract}
Stomatognathic system is strictly correlated to other anatomical regions; many studies investigated relationship between temporomandibular joint and posture, several articles describe cranio-facial pain from dental causes, such as trigger points. Until now less interest has been given to connections between dental occlusion and ophthalmology, even if they are important and involving. Clinical experience in dental practice claims that mandibular latero-deviation is connected both to eye dominance and to defects of ocular convergence. The trigeminal nerve is the largest and most complex of the twelve cranial nerves. The trigeminal system represents the connection between somitic structures and those derived from the branchial arches, collecting the proprioception from both somitic structures and oculomotor muscles. The intermedius nucleus of the medulla is a small perihypoglossal brainstem nucleus, which acts to integrate information from the head and neck and relays it on to the nucleus of the solitary tract where autonomic responses are generated. This intriguing neurophysiological web led our research group to investigate anatomical and functional associations between dental occlusion and vision. In conclusion, nervous system and functional pathways strictly connect vision and dental occlusion, and in the future both dentists and oculists should be more and more aware of this correlation for a better diagnosis and therapy.
\end{abstract}

Keywords: Cranial nerves, Dental occlusion, Mandibular latero-deviation, Ophthalmology, Trigeminal nerve.

\section{INTRODUCTION}

Clinical experience in dental practice claims that some cranio-mandibular characteristics could be connected both to eye functions and functional defects $[1,2]$.

Authors in a theoretical model demonstrated, for example, that rapid orthopedic maxillary expansion of the palate causes strains on structures directly and not directly joined with maxillary bones possibly reflecting on anatomy and function of oculomotor visual systems [3].

Stomatognathic system is correlated to other systems and anatomic regions; many studies investigated relationship between temporomandibular joint and posture, several articles describe cranio-facial pain originating from a different anatomical region, such as trigger points [4 - 9]. Until now less interest has been given to connections between dental occlusion and ophthalmology.

The trigeminal nerve is the largest and most complex of the twelve cranial nerves. It supplies sensations to the face, mucous membranes, and other structures of the head. It is the motor nerve for the muscles of mastication and contains proprioceptive fibers $[10-12]$.

On the other hand some anatomic studies related the trigeminal nuclear complex to several others nuclei of the brainstem linking trigeminal function to facial, hypoglossal, cochlear function [13 - 16], vagal/parasymphatetic [17 20] function and for the purpose of this review to collicular and oculomotor system [21 - 24].

\footnotetext{
* Address correspondence to this author at the University of L'Aquila, Department of Life, Health and Environmental Sciences, Building Delta 6 Dental Unit, St Salvatore Hospital-Via Vetoio 67100 L’Aquila, Italy; Tel: +39 3334474618; E-mails: nic.marc@hotmail.it, nicola.marchili@graduate.univaq.it
} 
This integration justifies functional union among neck, head, tongue and vegetative answers inducted by postural variations of every element of this circuit, among them also some afferent fibers to intermediate nucleus coming from vestibular and oculomotor nucleus [25].

The goal of this review is to analyze the current literature on the research findings on the relationship between stomatognathic and visual systems in order to confirm the anatomical and clinical suggestions above mentioned.

\section{METHODS}

\section{Research Strategy}

A literature search was performed searching English-language articles. The following electronic databases were selected: PubMed, Google Scholar and Scopus. It was not possible to make a temporal restriction (usually literature reviews are limited to the last ten years) because of lack of papers about correlations between dental occlusion and vision. The database queries were performed independently by three reviewers according to key words listed in Table $\mathbf{1}$. Animal studies, abstracts, letters, case reports, and reviews were excluded. Disagreement regarding inclusion was resolved by discussion. To avoid inappropriate exclusions, adjectives, nouns, plural and singular forms of all terms were used.

Table 1. Electronic databases used and search strategy.

\begin{tabular}{|c|c|}
\hline Database & $\begin{array}{c}\text { Search Strategy } \\
\text { Keywords/MeSH }\end{array}$ \\
\hline Pubmed & Dental occlusion OR \\
Temporomandibular joint(s) OR \\
Tmj OR \\
Lower Jaw OR \\
Mandible AND \\
Ophthalmology OR \\
Vision OR \\
\hline Google Scholar & Pupil(s) OR \\
scholar.google.it & Strabism OR \\
\hline Scopus & Myopia OR \\
www.scopus.com/home.url & Astigmatism OR \\
\hline
\end{tabular}

In addition, a manual search was performed in the following journals: Journal of Clinical Pediatric Dentistry, European Journal of Paediatric Dentistry. The search resulted in a total of thirteen articles and, subsequently, a final eligibility screening was conducted to verify the agreement with the inclusion and exclusion criteria listed below.

\section{Inclusion Criteria}

- Randomized controlled trials (RCTs) and historical controls for clinical trials (HCTs).

- Studies about functional relationship between gnathology and vision.

\section{Exclusion Criteria}

- Studies involving patients with systemic diseases such as oculo-facio-cardio-dental syndrome, psychosocial impairment, craniofacial abnormalities.

- Studies about connections between mouth and eyes in facial traumas, such as oral and maxillofacial surgery articles.

- Studies about connections between oral anesthesia (both plexic and troncular blocks) and vision.

- Studies about relationship between endodontics and eye infections.

- Studies about association between periodontology and anterior scleritis.

- No data for the evaluation of inclusion/exclusion criteria.

A total of eight articles were included according to both inclusion and exclusion criteria. These are summarized in Table 2 with notations regarding Authors, year of publication and sample size. 
Table 2. Characteristics of the reviewed papers.

\begin{tabular}{|c|c|c|c|c|}
\hline Study & $\begin{array}{l}\text { Sample } \\
\text { Size }\end{array}$ & Study Design & Age & Sex \\
\hline$[35]$ & 216 & $\begin{array}{l}119 \text { patients class I, } 62 \text { patients class II division } 1,15 \text { patients } \\
\text { class II division } 2,20 \text { patients class III }\end{array}$ & $11.4 \pm 1.2$ years & $\begin{array}{l}96 \text { males, } 120 \\
\text { females }\end{array}$ \\
\hline$[36]$ & 146 & $\begin{array}{l}122 \text { patients Class I, } 26 \text { patients Class II.1, } 9 \text { patients Class II.2, } 19 \\
\text { Class III; } 39 \text { patients with cross-bite and } 137 \text { without cross-bite }\end{array}$ & $12.4 \pm 2.1$ years & $\begin{array}{l}65 \text { males and } 81 \\
\text { females }\end{array}$ \\
\hline$[30]$ & 20 & $\begin{array}{l}10 \text { children with myopic defects } \\
10 \text { children with normal vision }\end{array}$ & $\begin{array}{c}\text { Mean age } 9 \pm 8 \text { months, between } 7 \text { and } \\
13 \text { years }\end{array}$ & \\
\hline$[28]$ & 13 & $\begin{array}{l}\text { Healthy subjects in habitual dental occlusion and stimulating ANS } \\
\text { maintaining rest position }\end{array}$ & Mean age $27.1 \pm 6.9$ years & 5 females, 8 males \\
\hline$[31]$ & 20 & 10 subjects wearing eyeglasses, 10 without sight defects & Mean age $21.5 \pm 1.23$ years & $\begin{array}{l}12 \text { females and } 8 \\
\text { males }\end{array}$ \\
\hline$[27]$ & 20 & $\begin{array}{l}10 \text { males with polysomnographic diagnoses } \\
\text { of mild OSAS and } 10 \text { with AHI less than } 5\end{array}$ & $\begin{array}{l}\text { Mean age of study group } 43.62 \pm 4.64 \\
\quad \text { years } \\
\text { Mean age of control group } 41.78 \pm 7.45\end{array}$ & 20 males \\
\hline$[26]$ & 36 & $\begin{array}{l}18 \text { females with myogenous TMD } \\
18 \text { matched controls }\end{array}$ & Mean age $26.5 \pm 5.3$ years & 36 females \\
\hline [29] & 40 & $\begin{array}{l}20 \text { RDC / TMD patients } \\
20 \text { controls }\end{array}$ & Less than 30 years & 40 females \\
\hline$[32]$ & 40 & 20 air force pilots 20 civilian pilots & $\begin{array}{c}\text { Mean age } 35.15 \pm 8.14 \text { years in air } \\
\text { force group } \\
\text { Mean age } 34.23 \pm 9.13 \text { years in } \\
\text { civilian pilots group }\end{array}$ & 40 males \\
\hline$[33]$ & 100 & $\begin{array}{l}50 \text { symptomatic patients with bilateral TMJ disc displacement } \\
50 \text { asymptomatic patients with normal disc position }\end{array}$ & $\begin{array}{l}\text { Study group: } 13 \text { men, } 37 \text { women; } \\
\text { mean age, } 28.84 \pm 8.22 \text { years } \\
\text { Control group: } 14 \text { men, } 36 \text { women; } \\
\text { mean age, } \\
\quad 29.96 \pm 5.04 \text { years }\end{array}$ & \\
\hline$[2]$ & 120 & $\begin{array}{c}60 \text { presenting mandibular latero-deviation, } 60 \text { without functional } \\
\text { mandibular laterodeviation }\end{array}$ & $\begin{array}{c}\text { From } 4 \text { to } 11 \text { years (mean age } 7 \\
\text { years) }\end{array}$ & $\begin{array}{c}\text { Study group: } 36 \\
\text { males, } 24 \text { females } \\
\text { Control group: } \\
\text { matching gender and } \\
\text { age case control. } \\
\end{array}$ \\
\hline$[34]$ & 36 & 18 permit holders shooters, 18 controls & & 36 males \\
\hline$[1]$ & 50 & 25 TMD patients 25 non-TMD control subjects & $\begin{array}{c}\text { Average age in TMD group: } 31 \text { years } \\
\text { Average age in control group: } 28 \\
\text { years }\end{array}$ & 50 females \\
\hline
\end{tabular}

\section{RESULTS}

Thirteen studies were identified for the aim of our paper. Four studies [26 - 29] by Monaco et al. analyzed pupil dynamics in patients affected from temporomandibular disorders and in other patients affected by sleep apnea, two studies examined the role of surface electromyography of masticatory and postural muscles to investigate ophthalmic system [30, 31], one article correlated dental occlusion, gaze and body posture [32], one article investigated the binocular motility system in patients suffering from TMJ internal derangement [33], one paper analyzes how dental occlusion modifies vision [34], two studies investigated connections between malocclusions and myopia [35] and astigmatism [36] and two publications investigated connections between mandibular deviations and vision [1,2].

857 people were investigated in the selected works. Among them 465 females and 372 males. Two studies focused on children (mean age 7.4 years), 48 females and 72 males, two studies on adolescents (mean age 11.8 years, 201 females and 161 males), and nine studies on adults (mean age 24.2 years, 139 males and 216 females) (Table $\mathbf{3}$ ).

Table 3. People investigated by selected works.

\begin{tabular}{|c|c|c|c|}
\hline & Children & Adolescents & 161 \\
\hline & 201 & 139 \\
\hline Males & 72 & 11.8 years & 216 \\
\hline Females & 48 & 24.2 years \\
\hline
\end{tabular}


In the selected studies people investigated belonged showed different clinical characteristics. Those characteristics are evidenced in the following pie charts: In Fig. (1) it is shown that 282 were healthy volunteers (mean age 23.9 years, 148 males and 134 females) among them 40 were pilots, 18 permit holders shooters, in Fig. (2) it is possible to notice that 173 were TMD ( mean age 20.02 years, 49 males and 124 females).

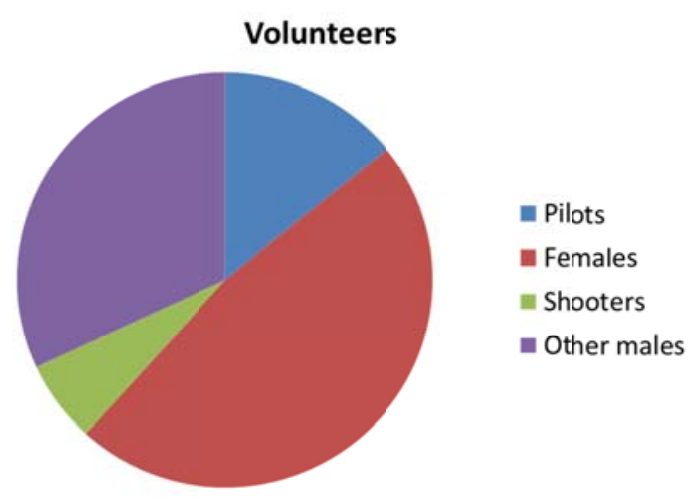

Fig. (1). Among 282 healthy volunteers, 134 were females, 40 were pilots, 18 were permit holders shooters and other 90 were other males.

\section{TMD patients}

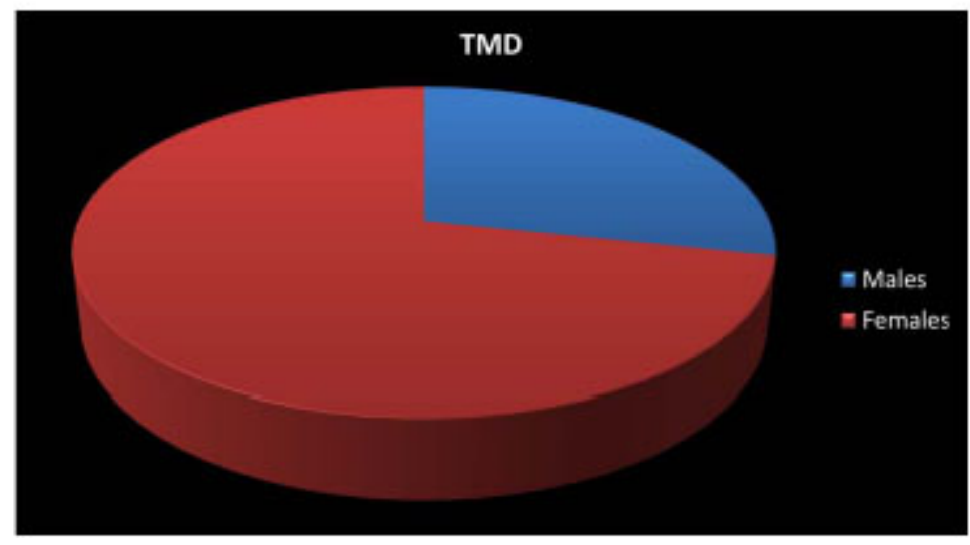

Fig. (2). Among TMD patients, 49 were males and 124 females.

Many studies conducted by Monaco et al. showed the presence of a relationship between malocclusions, temporomandibular disorders and visual defects, remarking a higher prevalence of myopia in patients with class II malocclusions than in patients with class I and III malocclusions, as well as a higher prevalence of patients with astigmatism and cross-bite (Table 4). Monaco et al. [30] underlined that a change in the visual input does not elicit an alteration in the stomatognathic muscles system basic activity in children with healthy vision, while the myopic children showed an enhancement of anterior temporal tone at rest.

Table 4. Myopia had a significantly greater prevalence in Class II patients [35].

\begin{tabular}{|c|c|c|c|c|c|}
\hline $\begin{array}{c}\text { Type of } \\
\text { visual defect }\end{array}$ & Class I (n=119) & Class II (n=62) & Class II Division 2 (n=15) & Class III (n=20) & Results of $\boldsymbol{\chi 2}$ test \\
\hline & $\mathrm{n}-\%$ & $\mathrm{n}-\%$ & $\mathrm{n}-\%$ & $\mathrm{n}-\%$ & $\mathrm{\%}$ \\
\hline Myopic & $21-9.7 \%$ & $42-19.4 \%$ & $6-2.7 \%$ & $3-1.3 \%$ & $\mathrm{p}<0.0001$ \\
\hline Non-myopic & $98-45.3 \%$ & $20-9.25 \%$ & $9-4.1 \%$ & $17-7.8 \%$ & $\mathrm{p}<0.005$ \\
\hline
\end{tabular}

Several studies assessed both anatomical and clinical effects of rapid maxillary expansion [3, 37 - 42]. Leonardi et al. demonstrated that the spheno-occipital synchondrosis is involved during RME therapy in youngsters; for the first time in humans, it is known to widen in response to midpalatal suture expansion (Table 5). Baldawa et al. warned that 
rapid maxillary expansion should be used carefully in adults, because of its far-reaching effects involving heavy stresses being noted at the sphenoid bone, zygomatic bone, nasal bone, and their adjacent sutures. Ortu et al. stated that there is even an evident change in the position of the head after the rapid palatal expansion.

Table 5. The clinician should realize that with activation of the RME appliance he/she is also forces on other structures that may or may not be beneficial for the patient [42].

\begin{tabular}{|c|c|c|c|}
\hline Sutures & $\begin{array}{c}\text { Maximum von Mises Stress Values, } \\
\mathbf{k g} / \mathbf{m m}^{\mathbf{2}}\end{array}$ & $\begin{array}{c}\text { Minimum von Mises Stress Values, } \\
\mathbf{k g} / \mathbf{m m}^{\mathbf{2}}\end{array}$ & $\begin{array}{c}\text { Average von Mises Stress Values, } \\
\mathbf{k g} / \mathbf{m m}^{\mathbf{2}}\end{array}$ \\
\hline Internasal & 55.4 & 7.22 & 19.18 \\
\hline Nasofrontal & 32.7 & 8.13 & 15.82 \\
\hline Nasomaxillary & 25.6 & 12.8 & 19.46 \\
\hline Frontomaxillary & 9.38 & 8.11 & 8.67 \\
\hline Zygomaticomaxillary & 8.95 & 2.85 & 5.71 \\
\hline Zygomaticofrontal & 33.0 & 4.11 & 14.42 \\
\hline Zygomaticotemporal & 9.27 & 1.99 & 5.24 \\
\hline
\end{tabular}

Computational result of the Von-Mises stress distribution on the various sutures of the craniofacial complex following 5 mm of transverse expansion.

\section{DISCUSSION}

Authors' primary goal is to give clinical advice starting from the study of anatomical and functional connection between dental occlusion and vision. Monaco et al. published several articles investigating these links, from mydriasis in patients affected from temporomandibular disorders to a provision of glasses under surface electromyography (sEMG) control. Monaco et al. [30] noticed a significant change in sEMG activity, mainly observed at opening eyes in myopic children. This phenomenon suggests that a bioelectric device as electromyography could help the diagnosis of vision problems in unaware patients or to control lenses adequacy. Anterior temporal tone increase for worsening of visual defects could be associated to episodic tension-type headache with enhanced levels of tenderness and/or sEMG of masticatory and postural muscles and clinically relevant in differential diagnosis of headache. Mesin et al. [28] claimed that pupillogram is a reliable device to inspect the condition of the autonomous nervous system (ANS). A simple, short, not expensive protocol (suitable for a clinical setting) is proposed, based on the investigation of pupil dynamics in darkness with the mandible in rest position (RP) or during a habitual dental occlusion (HDO). The joint analysis of linear and Recurrent Quantification Analysis indexes extracted from the pupillogram is sensitive enough to discriminate between these two conditions, determining weakly different stimulations of the Autonomous Nervous System. Fiorucci et al. [31] affirmed that by considering the parameters measured by the proposed system, it is possible to state the right choice for the degree of eyeglasses or contact lenses, with a direct and objective evaluation of the generated muscular stress. To extract useful information about the effect of incorrect lenses, the electromyography signal in rest conditions should be suitably acquired and processed in order to both reduce the effect of the noise and to supply the oculist with a reliable quantitative indication. The pupil size data collected and analyzed by Monaco et al. [27] show that patients affected by obstructive sleep apnea syndrome (OSAS) show different behaviors compared to the control subjects under infrared conditions. These data indicate that OSAS patients could suffer from a dysregulation of vegetative control probably due to difficulties in inhibiting cholinergic pathways during activation of adrenergic ones at the pupil level to properly respond to activation (lack of light and muscular stress). Monaco et al. [29] in a recent study found no significant difference in pupil size in darkness between the control and TMD groups. On the contrary, They found significant within-group differences in pupil size in the darkness condition before TENS compared with during TENS in both the control and TMD groups; precisely, the pupil size was reduced during TENS. Significant differences in pupil size in the darkness condition were found pre- compared with post-TENS in the control group but not in the TMD group. In the control group, the pupil size was reduced post-TENS, with the same reduction obtained during TENS; in the TMD group, the size of the pupil post-TENS got back close to the pre-TENS value. Significant differences in pupil size in the light condition were found between the control and TMD groups; specifically, the TMD group showed a significantly smaller pupil size. Significant within-group differences in pupil size in the light condition were found pre-TENS compared with during TENS and pre-TENS compared with post-TENS in the control group but not in the TMD group; pupil size in the light condition was reduced just in the control group. Monaco et al. [29] assessed that TMD patients show values of pupil size bigger in Rest mandible position (RP) infrared and lower in RP light condition than healthy subjects, although not statistically significant; under the stress of forced habitual occlusion (FHO) TMD patients have a different reaction compared to healthy subjects: Forced Habitual Occlusion/Rest mandible Position ratio in darkness and light/darkness ratio in Rest Position have significantly different behavior in the two 
groups. Control subjects increased, while TMD patients decreased pupil size at FHO in infrared lightening. In infrared conditions FHO/RP ratio is significantly greater in control group as well as light/darkness ratio at RP. Pupil size in RP infrared is greater in healthy people than in TMD group. The discrepancy between groups does not indicate statistical significance, probably because of dispersion of values. On the contrary, comparison within group at infrared lighting shows that FHO pupil size of the healthy subjects increases highly compared to RP, while FHO pupil size of TMD subjects decreases significantly. Pupil size is modulated by a tricky interaction between sympathetic and parasympathetic branches of ANS: the first uses mainly adrenergic, the second cholinergic pathway. Both muscles of iris (sphincter and dilator) get reciprocal innervations from the 2 branches of ANS providing contraction and inhibition (or relaxation). Parasympathetic cholinergic fibers, from Edinger-Wesphal Nucleus, supply the iris sphincter acting for contraction of the muscle and so reduction of the pupil size. At the same time, the sphincter receives beta-adrenergic innervations able to decrease the contraction providing relaxation of the muscle. In humans pupil dilation obtained by beta-adrenergic inhibition of sphincter can be less than half of the maximum physiological dilation. Iris dilator muscle mostly receives a adrenergic sympathetic motor innervation (Budge's Cilio Spinal Center) eliciting contraction and so enhancing pupil size. Dilator muscle contraction is mediated by alpha-adrenergic receptors and inhibition or relaxation may be acted by muscarinic receptors and, maybe, by beta-adrenergic innervations. Dysregulated balance between ANS branches may lead to a deficit of inhibitory effect. Defect in beta-adrenergic or muscarinic inhibition that counteracts the action of alpha-adrenergic contraction of the dilator may result in bigger pupil size in obscurity and reduction of beta-adrenergic inhibition on cholinergic system of sphincter muscle could lead to increase of myosis. For Baldini et al. [32] mandibular position influences the sway area with good statistical significance in pilots, but not the sway velocity. The pilot's postural equilibrium worsened in the centric occlusion mandibular position, thus indicating that dental occlusion had a negative influence on body posture. This may be due to the peculiar condition of the pilots' stomatognathic system, stressed by bruxism and the effect of in-flight forces. Pilots have a better postural control than normal individuals in all occlusal and visual combinations. A wrong fabrication of occlusal splints for protecting the stomatognathic system can unbalance the postural system, predisposing to an even higher incidence of posture-related symptomatologies. Briefly, vision exercises a central role in the postural system of air force and civilian pilots, the visual function allows for better postural control. Anatomic connections were shown between the trigeminal and oculomotor systems. In the mesencephalic nucleus of the trigeminus, which extends from the dorsal portion of the spinal trigeminal nucleus to the caudal part of the superior colliculus, connections associated with the extraocular muscles are present [33]. Buisseret-Delmas and Buiseret used a peroxidase injection into the oculomotor muscles as a marker that diffuses in the Gasser ganglium, in the pars interpolaris and caudalis of the spinal trigeminal nucleus, in the paratrigeminal nucleus, and in the dorsal horn of the cervical spinal cord [43]. The main nucleus of the trigeminus and the oral, interpolar, and caudal portions of the spinal trigeminal nucleus are connected with the vestibular nucleus and the prepositus nucleus of the hypoglossus. This nucleus is part of a small group of neurons adjacent to the nucleus of the hypoglossus, but they are not matched; it is also an important center of elaboration of the position and movements of the eyes, because of its strict relationship with the vestibular nuclei, the cerebellum, and the oculomotor nuclei [44]. Cuccia et al. found that patients suffering from TMJ internal derangement showed reduced convergence compared with the healthy subjects, particularly the patients affected by disc displacement without reduction. Moreover, a positive fusional convergence reduction was found in the internal derangement patients. The normal alignment of the eyes is maintained by their fusional movements. The reflex is driven by retinal image disparity. In normal conditions, retinal image disparity produces diplopia. Fusional movements then trigger a vergency response to align the images of the object in regard to the foveas. Near positive fusional vergence measures the extent to which a person can maintain fusion with gradually increasing vergence demands. Altered ocular movements in TMD patients may be related to dysfunction in Superior Colliculus, a relay center in the midbrain receiving visual, somesthetic, and proprioceptive afferent fibers and is involved in postural motor and gait control as well as gaze movements. Bilateral trigeminocollicular connections have been described in pigs, rats, and cats, and this connection is of interest particularly for the principal trigeminal nucleus [45]. Cuccia, et al. discussed the relationship among dental occlusion, the oculomotor system, and visual stabilization. Evidence of a correlation between eye and dental occlusion also came from the use of Gelb mandibular orthopedic repositioning appliances (MORAs), which simultaneously modify mandibular position and visual focusing tests using the Maddox rod and the Berens prismatic bars. Holfberg et al. assessed that the superior orbital fissure, that oval foramen, the spinous foramen, the round foramen, the lacerated foramen, the optic foramen, and the carotid sulcus are particularly affected by rapid palatal suture expansion. Jafari et al. warned the clinician to realize that with activation of the rapid maxillary expansion appliance he/she is producing not only an expansion force at the intermaxillary suture but also forces on other structures within the craniofacial complex that may or may not be beneficial for the patient, confirming what Monaco clinically evalued, that is an exophoria-tropia may turn into a simple 
exophoria after palatal expansion [3]. It is evidence-based that TMJ examination should include the extraocular musculature. Dysfunctional afferences carried by the trigeminal system, deriving from lesions in the masticatory muscles or the TMJ, can involve binocular function, because of the functional relationship between the trigeminal and oculomotor systems. The oculomotor function must be assessed as important as the TMD, because the visual function is the most important afferent pathway in posture. In conclusion, nervous system and functional pathways strictly connect vision and dental occlusion, and in the future both dentists and oculists should be more and more aware of this correlation for a better diagnosis and therapy.

\section{CONFLICT OF INTEREST}

The authors confirm that this article content has no conflicts of interest.

\section{ACKNOWLEDGEMENTS}

Declared none.

\section{REFERENCES}

[1] Pradham NS, White GE, Mehta N, Forgione A. Mandibular deviations in TMD and non-TMD groups related to eye dominance and head posture. J Clin Pediatr Dent 2001; 25(2): 147-55. [http://dx.doi.org/10.17796/jcpd.25.2.j7171238p2413611] [PMID: 11314215]

[2] Monaco A, Streni O, Marci MC, Sabetti L, Marzo G, Giannoni M. Relationship between mandibular deviation and ocular convergence. J Clin Pediatr Dent 2004; 28(2): 135-8. [http://dx.doi.org/10.17796/jcpd.28.2.mj7311103m257134] [PMID: 14969372]

[3] Monaco A, Tepedino M, Sabetti L, Petrucci A, Sgolastra F. An adolescent treated with rapid maxillary expansion presenting with strabismus: a case report. J Med Case Reports 2013; 7: 222. [http://dx.doi.org/10.1186/1752-1947-7-222] [PMID: 23971857]

[4] Pal US, Kumar L, Mehta G, et al. Trends in management of myofacial pain. Natl J Maxillofac Surg 2014; 5(2): 109-16. [http://dx.doi.org/10.4103/0975-5950.154810] [PMID: 25937719]

[5] Firmani M, Miralles R, Casassus R. Effect of lidocaine patches on upper trapezius EMG activity and pain intensity in patients with myofascial trigger points: A randomized clinical study. Acta Odontol Scand 2015; 73(3): 210-8. [http://dx.doi.org/10.3109/00016357.2014.982704] [PMID: 25428627]

[6] Yu SH, Kim HJ. Electrophysiological characteristics according to activity level of myofascial trigger points. J Phys Ther Sci 2015; 27(9): 2841-3. [http://dx.doi.org/10.1589/jpts.27.2841] [PMID: 26504306]

[7] Lluch E, Nijs J, De Kooning M, et al. Prevalence, incidence, localization, and pathophysiology of myofascial trigger points in patients with spinal pain: a systematic literature review. J Manipulative Physiol Ther 2015; 38(8): 587-600. [http://dx.doi.org/10.1016/j.jmpt.2015.08.004] [PMID: 26387860]

[8] Chiarotto A, Clijsen R, Fernandez-de-Las-Penas C, Barbero M. Prevalence of myofascial trigger points in spinal disorders: a systematic review and meta-analysis. Arch Phys Med Rehabil 2016; 97(2): 316-37. [http://dx.doi.org/10.1016/j.apmr.2015.09.021] [PMID: 26475933]

[9] Monaco A, Spadaro A, Cattaneo R, Giannoni M. Effects of myogenous facial pain on muscle activity of head and neck. Int J Oral Maxillofac Surg 2010; 39(8): 767-73.

[http://dx.doi.org/10.1016/j.ijom.2010.03.025] [PMID: 20439150]

[10] Klasser GD, Okeson JP. Role of the dentist in the management of orofacial pain. Pain Manag 2015; 5(6): 407-11. [http://dx.doi.org/10.2217/pmt.15.40] [PMID: 26400752]

[11] Hilgenberg-Sydney PB, Kowacs PA, Conti PC. Somatosensory evaluation in dysfunctional syndrome patients. J Oral Rehabil 2016; 43(2): 89-95.

[http://dx.doi.org/10.1111/joor.12344] [PMID: 26337788]

[12] Avivi-Arber L, Lee JC, Sessle BJ. Dental occlusal changes induce motor cortex neuroplasticity. J Dent Res 2015; 94(12): 1757-64. [http://dx.doi.org/10.1177/0022034515602478] [PMID: 26310722]

[13] Zeng C, Shroff H, Shore SE. Cuneate and spinal trigeminal nucleus projections to the cochlear nucleus are differentially associated with vesicular glutamate transporter-2. Neuroscience 2011; 176: 142-51. [http://dx.doi.org/10.1016/j.neuroscience.2010.12.010] [PMID: 21167260]

[14] Zhou J, Nannapaneni N, Shore S. Vessicular glutamate transporters 1 and 2 are differentially associated with auditory nerve and spinal trigeminal inputs to the cochlear nucleus. J Comp Neurol 2007; 500(4): 777-87. [http://dx.doi.org/10.1002/cne.21208] [PMID: 17154258]

[15] Riemann R, Reuss S. Nitric oxide synthase in trigeminal ganglion cells projecting to the cochlea of rat and guinea pig. Neuroreport 1999; 10(12): 2641-5. 
[http://dx.doi.org/10.1097/00001756-199908200-00037] [PMID: 10574384]

[16] Shore SE, Vass Z, Wys NL, Altschuler RA. Trigeminal ganglion innervates the auditory brainstem. J Comp Neurol 2000; 419(3): 271-85. [http://dx.doi.org/10.1002/(SICI)1096-9861(20000410)419:3<271::AID-CNE1>3.0.CO;2-M] [PMID: 10723004]

[17] Bhargava D, Thomas S, Chakravorty N, Dutt A. Trigeminocardiac reflex: A reappraisal with relevance to maxillofacial surgery. J Maxillofac Oral Surg 2014; 13(4): 373-7. [http://dx.doi.org/10.1007/s12663-013-0541-4] [PMID: 26224999]

[18] Allen LE, Sudesh S, Sandramouli S, Cooper G, McFarlane D, Willshaw HE. The association between the oculocardiac reflex and postoperative vomiting in children undergoing strabismus surgery. Eye (Lond) 1998; 12(Pt 2): 193-6. [http://dx.doi.org/10.1038/eye.1998.46] [PMID: 9683936]

[19] Imbe H, Dubner R, Ren K. Masseteric inflammation-induced Fos protein expression in the trigeminal interpolaris/caudalis transition zone: contribution of somatosensory-vagal-adrenal integration. Brain Res 1999; 845(2): 165-75. [http://dx.doi.org/10.1016/S0006-8993(99)01913-7] [PMID: 10536195]

[20] Bereiter DA, Bereiter DF, Ramos M. Vagotomy prevents morphine-induced reduction in Fos-like immunoreactivity in trigeminal spinal nucleus produced after TMJ injury in a sex-dependent manner. Pain 2002; 96(1-2): 205-13. [http://dx.doi.org/10.1016/S0304-3959(01)00450-X] [PMID: 11932076]

[21] Venugopal S, Hsiao CF, Sonoda T, Wiedau-Pazos M, Chandler SH. Homeostatic dysregulation in membrane properties of masticatory motoneurons compared with oculomotor neurons in a mouse model for amyotrophic lateral sclerosis. J Neurosci 2015; 35(2): 707-20. [http://dx.doi.org/10.1523/JNEUROSCI.1682-14.2015] [PMID: 25589764]

[22] Ndiaye A, Pinganaud G, VanderWerf F, Buisseret-Delmas C, Buisseret P. Connections between the trigeminal mesencephalic nucleus and the superior colliculus in the rat. Neurosci Lett 2000; 294(1): 17-20. [http://dx.doi.org/10.1016/S0304-3940(00)01519-6] [PMID: 11044576]

[23] Guerra-Seijas MJ, Labandeira Garcia J, Tobio J, Gonzalez F. Neurons located in the trigeminal sensory complex and the lateral pontine tegmentum project to the oculomotor nucleus in the rabbit. Brain Res 1993; 601(1-2): 1-13. [http://dx.doi.org/10.1016/0006-8993(93)91689-P] [PMID: 8431757]

[24] Manni E, Draicchio F, Pettorossi VE, et al. On the nature of the afferent fibers of oculomotor nerve. Arch Ital Biol 1989; 127(2): 99-108. [PMID: 2719524]

[25] Edwards IJ, Deuchars SA, Deuchars J. The intermedius nucleus of the medulla: a potential site for the integration of cervical information and the generation of autonomic responses. J Chem Neuroanat 2009; 38(3): 166-75.

[http://dx.doi.org/10.1016/j.jchemneu.2009.01.001] [PMID: 19790285]

[26] Monaco A, Cattaneo R, Mesin L, Ortu E, Giannoni M, Pietropaoli D. Dysregulation of the descending pain system in temporomandibular disorders revealed by low-frequency sensory transcutaneous electrical nerve stimulation: a pupillometric study. PLoS One 2015; 10(4): e0122826.

[http://dx.doi.org/10.1371/journal.pone.0122826] [PMID: 25905862]

[27] Monaco A, Cattaneo R, Mesin L, Fiorucci E, Pietropaoli D. Evaluation of autonomic nervous system in sleep apnea patients using pupillometry under occlusal stress: a pilot study. Cranio 2014; 32(2): 139-47. [http://dx.doi.org/10.1179/0886963413Z.00000000022] [PMID: 24839725]

[28] Mesin L, Monaco A, Cattaneo R. Investigation of nonlinear pupil dynamics by recurrence quantification analysis. BioMed Res Int 2013 ; 11. [http://dx.doi.org/10.1155/2013/420509]

[29] Monaco A, Cattaneo R, Mesin L, Ciarrocchi I, Sgolastra F, Pietropaoli D. Dysregulation of the autonomous nervous system in patients with temporomandibular disorder: a pupillometric study. PLoS One 2012; 7(9): e45424. [http://dx.doi.org/10.1371/journal.pone.0045424] [PMID: 23028999]

[30] Monaco A, Cattaneo R, Spadaro A, Giannoni M, Di Martino S, Gatto R. Visual input effect on EMG activity of masticatory and postural muscles in healthy and in myopic children. Eur J Paediatr Dent 2006; 7(1): 18-22. [PMID: 16646640]

[31] Fiorucci EB, Cattaneo R, Monaco A. The measurement of surface electromyographic signal in rest position for the correct prescription of eyeglasses. IEEE Instrum Meas 2012; 61(2): 419-28. [http://dx.doi.org/10.1109/TIM.2011.2164838]

[32] Baldini A, Nota A, Cravino G, Cioffi C, Rinaldi A, Cozza P. Influence of vision and dental occlusion on body posture in pilots. Aviat Space Environ Med 2013; 84(8): 823-7. [http://dx.doi.org/10.3357/ASEM.3541.2013] [PMID: 23926657]

[33] Cuccia AM, Caradonna C. Binocular motility system and temporomandibular joint internal derangement: a study in adults 2008. [http://dx.doi.org/10.1016/j.ajodo.2007.10.034]

[34] Gangloff P, Louis JP, Perrin PP. Dental occlusion modifies gaze and posture stabilization in human subjects. Neurosci Lett 2000; 293(3): 203-6. [http://dx.doi.org/10.1016/S0304-3940(00)01528-7] [PMID: 11036196]

[35] Monaco A, Sgolastra F, Cattaneo R, et al. Prevalence of myopia in a population with malocclusions. Eur J Paediatr Dent 2012; 13(3)(Suppl.): $256-8$. 
[PMID: 23046255]

[36] Monaco A, Spadaro A, Sgolastra F, Petrucci A, D'Andrea PD, Gatto R. Prevalence of astigmatism in a paediatric population with malocclusions. Eur J Paediatr Dent 2011; 12(2): 91-4. [PMID: 21668278]

[37] Leonardi R, Cutrera A, Barbato E. Rapid maxillary expansion affects the spheno-occipital synchondrosis in youngsters. A study with lowdose computed tomography. Angle Orthod 2010; 80(1): 106-10. [http://dx.doi.org/10.2319/012709-56.1] [PMID: 19852648]

[38] Baldawa RS, Bhad WA. Stress distribution analysis during an intermaxillary dysjunction: A 3-D FEM study of an adult human skull. Ann Maxillofac Surg 2011; 1(1): 19-25. [http://dx.doi.org/10.4103/2231-0746.83148] [PMID: 23482925]

[39] Ortu E, Pietropaoli D, Ortu M, Giannoni M, Monaco A. Evaluation of cervical posture following rapid maxillary expansion: a review of literature. Open Dent J 2014; 8: 20-7.

[http://dx.doi.org/10.2174/1874210601408010020] [PMID: 24799964]

[40] Cuccia A, Caradonna C. The relationship between the stomatognathic system and body posture. Clinics (Sao Paulo) 2009; 64(1): 61-6. [http://dx.doi.org/10.1590/S1807-59322009000100011] [PMID: 19142553]

[41] Holberg C, Rudzki-Janson I. Stresses at the cranial base induced by rapid maxillary expansion. Angle Orthod 2006; 76(4): 543-50. [PMID: 16808557]

[42] Jafari A, Shetty KS, Kumar M. Study of stress distribution and displacement of various craniofacial structures following application of transverse orthopedic forces--a three-dimensional FEM study. Angle Orthod 2003; 73(1): 12-20. [PMID: 12607850]

[43] Buisseret-Delmas C, Buisseret P. Central projections of extraocular muscle afferents in cat. Neurosci Lett 1990; 109(1-2): 48-53. [http://dx.doi.org/10.1016/0304-3940(90)90536-I] [PMID: 1690368]

[44] Buisseret-Delmas C, Compoint C, Delfini C, Buisseret P. Organisation of reciprocal connections between trigeminal and vestibular nuclei in the rat. J Comp Neurol 1999; 409(1): 153-68.

[http://dx.doi.org/10.1002/(SICI)1096-9861(19990621)409:1<153::AID-CNE11>3.0.CO;2-\#] [PMID: 10363717]

[45] Dauvergne C, Ndiaye A, Buisseret-Delmas C, Buisseret P, Vanderwerf F, Pinganaud G. Projections from the superior colliculus to the trigeminal system and facial nucleus in the rat. J Comp Neurol 2004; 478(3): 233-47. [http://dx.doi.org/10.1002/cne.20262] [PMID: 15368536]

(C) Marchili et al.; Licensee Bentham Open

This is an open access article licensed under the terms of the Creative Commons Attribution-Non-Commercial 4.0 International Public License (CC BY-NC 4.0) (https://creativecommons.org/licenses/by-nc/4.0/legalcode), which permits unrestricted, non-commercial use, distribution and reproduction in any medium, provided the work is properly cited. 